\title{
Cannabis and Cannabis Derivatives for Abdominal Pain Management in Inflammatory Bowel Disease
}

\author{
Kaleb Bogale ${ }^{a}$ Wesley Raup-Konsavage ${ }^{b}$ Shannon Dalessio ${ }^{c}$ Kent Vrana ${ }^{b}$ \\ Matthew D. Coates ${ }^{b, c}$ \\ aPennsylvania State University College of Medicine, Hershey, PA, USA; ${ }^{b}$ Department of Pharmacology, Pennsylvania \\ State University College of Medicine, Hershey, PA, USA; 'Division of Gastroenterology \& Hepatology, Department of \\ Medicine, Pennsylvania State University College of Medicine, Hershey, PA, USA
}

\author{
Keywords \\ Inflammatory bowel disease - Crohn's disease - Ulcerative \\ colitis · Abdominal pain - Cannabis · Cannabinoids . \\ Endocannabinoid system
}

\begin{abstract}
For centuries, cannabis and its components have been used to manage a wide variety of symptoms associated with many illnesses. Gastrointestinal (Gl) diseases are no exception in this regard. Individuals suffering from inflammatory bowel disease (IBD) are among those who have sought out the ameliorating properties of this plant. As legal limitations of its use have eased, interest has grown from both patients and their providers regarding the potential of cannabis to be used in the clinical setting. Similarly, a growing number of animal and human studies have been undertaken to evaluate the impact of cannabis and cannabinoid signaling elements on the natural history of IBD and its associated complications. There is little clinical evidence supporting the ability of cannabis or related products to treat the GI inflammation underlying these disorders. However, 1 recurring theme from both animal and human studies is that these agents have a significant impact on several IBD-related
\end{abstract}

karger@karger.com www.karger.com/mca

Karger

bOPEN ACCESS
(C) 2021 The Author(s)

Published by S. Karger AG, Basel

This is an Open Access article licensed under the Creative Commons Attribution-NonCommercial-4.0 International License (CC BY-NC) (http://www.karger.com/Services/OpenAccessLicense), applicable to the online version of the article only. Usage and distribution for commercial purposes requires written permission. symptoms, including abdominal pain. In this review, we discuss the role of cannabis and cannabinoid signaling in visceral pain perception, what is currently known regarding the efficacy of cannabis and its derivatives for managing pain, related symptoms and inflammation in IBD, and what work remains to effectively utilize cannabis and its derivatives in the clinical setting.

(C) 2021 The Author(s)

Published by S. Karger AG, Basel

\section{Introduction}

Cannabis, also known as marijuana, refers to the plant belonging to the family Cannabaceae, the genus Cannabis, and the species Cannabis sativa (hereafter referred to as Cannabis) [1]. Cannabis use for medicinal purposes has been described for thousands of years [1]. Over the centuries, numerous potential health-related applications of Cannabis have been identified. Due to legal restrictions and cultural and societal stigma associated with its use, Cannabis has been notoriously difficult to study in the USA, particularly for biomedical purposes. However, over the past few decades, Cannabis has enjoyed increasing mainstream cultural acceptance as well as legal- 
ization in several countries around the world [2]. In the USA, as of February 2021, thirty-four states and the District of Columbia currently have passed laws broadly legalizing or decriminalizing Cannabis in some form $[3,4]$. Several states have approved the use of so-called medical marijuana for a variety of conditions, including as an alternative or adjuvant therapy for the inflammatory bowel diseases (IBD), Crohn's disease (CD), and ulcerative colitis (UC) $[3,5]$. Recent studies suggest that $10-12 \%$ of IBD patients utilize Cannabis at least intermittently to address their symptoms [6-10]. Due to increasing acceptance and availability of Cannabis, patients have expressed growing interest in the therapeutic potential of this agent and its derivatives. As a result, health-care providers are increasingly relied upon to provide advice about Cannabis and its promise as a treatment for IBD [11].

Developing a clear scientific understanding of the impact of Cannabis in the setting of IBD has been challenging, however. Multiple studies utilizing animal models of enterocolitis provide evidence that the endocannabinoid system (ECS) can have a powerful influence on gastrointestinal (GI) inflammation and proxy measures of motility and visceral sensitivity [12]. On the other hand, studies that have looked at Cannabis or cannabinoid derivatives (including inhaled and oral tetrahydrocannabinol (THC), Cannabis derivatives including synthetic THC (dronabinol) or endocannabinoid ligands (palmitoylethanolamide), and phytocannabinoids (cannabidiol [CBD] oil)) in the setting of human IBD have shown no objective evidence for modulation of disease-related inflammation [13-16].

However, multiple human studies have demonstrated that Cannabis has a positive impact on a variety of symptoms, including abdominal pain [13, 17]. Unsurprisingly, IBD patients who use Cannabis or related products frequently report taking it specifically for abdominal pain management, including approximately $90 \%$ of a cohort in 1 study [9]. Thus, while it is not clear that Cannabis helps IBD-associated inflammation, mounting evidence suggests that Cannabis may be an effective analgesic option for IBD-associated abdominal pain and many patients are already using for this purpose. Accordingly, it is critical for IBD providers to have a clear understanding of what the scientific literature can and cannot tell us about cannabinoid use in this setting.

The purpose of this review is to highlight recent developments relating to the use of Cannabis and its derivatives for the management of IBD and the abdominal pain associated with these conditions. We will present an overview of the ECS, focusing primarily on its role in the GI tract and visceral nociceptive pathways. We will also review what is currently known about cannabinoid signaling in the context of IBD, IBD-associated pain, and conditions associated with altered abdominal pain perception. Finally, we will discuss the current gaps in knowledge on this subject as well as potential future research directions.

\section{Methods}

We conducted a series of MEDLINE searches spanning 20012021 analyzing Cannabis (or any Cannabis derivative or synthetic cannabinoid) consumption among patients with IBD. Each study was classified by the study design, which included randomized controlled trials, retrospective and prospective clinical studies, and tolerance studies assembled using a combination of medical subject heading and free-text search terms. We also classified studies based on the dosage of Cannabis or cannabinoid derivative (or lack thereof) and the method of consumption (inhaled, oral, and oromucosal). The primary outcome variable was the modulation of IBD-related abdominal pain, with secondary outcome variables of IBD disease activity, quality of life, and influence of other IBDrelated symptoms.

Medline searches included the following terms: Cannabis + IBD/Inflammatory bowel disease; Cannabis + IBD/Inflammatory bowel disease + RCT/Randomized controlled trial; Cannabis + IBD/Inflammatory bowel disease + abdominal pain; Cannabis + abdominal pain; THC/Tetrahydrocannabinol + IBD/Inflammatory Bowel Disease; CBD/Cannabidiol + IBD/Inflammatory Bowel Disease; marijuana + IBD/Inflammatory Bowel Disease; marijuana + IBD/Inflammatory bowel disease + RCT/Randomized controlled trial; marijuana + IBD/Inflammatory bowel disease + abdominal pain; PEA/palmitoylethanolamide + IBD/Inflammatory Bowel Disease; Anandamide + IBD/Inflammatory Bowel Disease; Anandamide + IBD/Inflammatory bowel disease + pain; 2-AG/2-Arachidonoylglycerol + IBD/Inflammatory Bowel Disease.

\section{Overview of ECS}

The ECS encompasses structures and physiological processes within the body that mediate the effects of cannabinoids. The ECS includes cellular receptors, endogenous ligands of those receptors, termed endocannabinoids, and the enzyme regulators of endocannabinoid production and metabolism $[18,19]$. There are at least 2 G-protein-coupled receptors, known as cannabinoid type-1 and type- 2 receptors $\left(\mathrm{CB}_{1} \mathrm{R}\right.$ and $\left.\mathrm{CB}_{2} \mathrm{R}\right)$, linked to $G_{i}$ proteins that inhibit adenylate cyclase conversion of ATP to cyclic AMP and also inhibit neuronal firing [20]. There are additional cellular mediators involved in ECS modulation that we will not discuss in significant detail here. For example, in addition to $\mathrm{CB}_{1} \mathrm{R}$ and $\mathrm{CB}_{2} \mathrm{R}$ signaling in the gut, there are other receptors that respond to the endocannabinoids such as the G-protein-coupled receptor 55 (GPR55), the transient receptor potential cation channel subfamily V (vanilloid) member 1 (TRPV1), and peroxisome proliferatoractivated receptors alpha and gamma (PPAR $\boldsymbol{\alpha}$ and PPAR $\gamma$ ) [19]. Additional information regarding the general properties of those intracellular mediators of the ECS can be found in the reviews referenced here $[19,21,22]$.
Med Cannabis Cannabinoids 2021;4:97-106 DOI: 10.1159/000517425
Bogale/Raup-Konsavage/Dalessio/Vrana/ Coates 
$\mathrm{CB}_{1} \mathrm{Rs}$ are distributed throughout the central nervous system and throughout peripheral tissues including the GI tract, liver, skeletal muscle, cardiovascular tissue, reproductive tissue, and adipose tissue [23]. $\mathrm{CB}_{2}$ Rs are found on immune cells, as well as within the central nervous system, including microglia, and the GI tract [20]. The primary endocannabinoids are 2-arachidonoylglycerol (2-AG) [24], which binds $\mathrm{CB}_{1} \mathrm{R}$ and $\mathrm{CB}_{2} \mathrm{R}$ equally, and anandamide (arachidonoylethanolamine [AEA]) [25], which binds $\mathrm{CB}_{1} \mathrm{R}$ with greater affinity than $\mathrm{CB}_{2} \mathrm{R}$. The plant-derived phytocannabinoids delta-9-THC is a partial, nonselective agonist of $\mathrm{CB}_{1} \mathrm{R}$ and $\mathrm{CB}_{2} \mathrm{R}$. Some synthetic cannabinoids are nonselective, full agonists of $\mathrm{CB}_{1} \mathrm{R}$ and $\mathrm{CB}_{2} \mathrm{R}$ (HU-210 [26], CP 55,940 [27], SAB378 [peripherally restricted] $[26,28])$, while others are full agonists for both $\mathrm{CB}_{1} \mathrm{R}$ and $\mathrm{CB}_{2} \mathrm{R}$ with an increased selectivity for either $\mathrm{CB}_{1} \mathrm{R}$ (2-arachidonoyl glyceryl ether [noladine ether] [29]) or $\mathrm{CB}_{2} \mathrm{R}$ (WIN55,212-2) [27]. There are $\mathrm{CB}_{1} \mathrm{R}$-selective agonists (arachidonyl-2'-chloroethylamide, ACEA [30]) and $\mathrm{CB}_{1} \mathrm{R}$ antagonists, which may be further classified as first-generation (SR141716A [Rimonabant] [31,32] and AM251) for their generalized systemic effects or second-generation (TM38837, AM6545, and JD5037 [22]) for peripherally limited effects. Similarly, there are $\mathrm{CB}_{2} \mathrm{R}$-selective agonists (JWH-133 [26, 33], JWH-015, AM1241, HU-308 [26], and GP1a [34]) and $\mathrm{CB}_{2} \mathrm{R}$-specific antagonists (SR144528 [35] and AM630) [27]. Functional relationships between $\mathrm{CB}_{1}$ Rs and $\mathrm{CB}_{2}$ Rs are dependent on their location and local function, as they may work in unison, compete with, or oppose each other's actions [36].

Importantly, the ECS also includes the modulators of the endocannabinoids anandamide (AEA) and 2-AG $[24,25]$. Both AEA and $2-A G$ are synthesized from unique membrane-bound arachidonic acid precursors and hydrolyzed by fatty acid amide hydrolase (FAAH) and monoglyceride lipase (MGL), respectively. Inhibition of FAAH (by specific inhibitors including PF-04457845 [37], URB597 [38], and PF-3845 [39]) or MGL (by antagonists JZL184 [40], KML29 [41], JW651 [42], JJKK-048 [43], and MJN110 [44]) increase levels of AEA and 2-AG, respectively. Additionally, there are nonselective inhibitors, such as JZL195 [40] that antagonize both FAAH and MGL, leading to an overall increase in ECS activity. This demonstrates that there are myriad pharmacological tools available to study the role of the ECS in IBD.

\section{Cannabinoid Signaling within the GI Tract}

The ECS plays a crucial role in every major aspect of GI function and physiology, including motility, mucosal secretion, visceral pain perception, and epithelial barrier function $[19,45]$. A careful evaluation reveals how prevalent ECS components are within the gut. Immunohistochemistry of human colonic tissues identified $\mathrm{CB}_{1} \mathrm{R}$ within normal colonic epithelium, smooth muscle, and submucosal-myenteric plexus, with co-expression of $\mathrm{CB}_{2} \mathrm{R}$ on plasma cells and lamina propria [46]. $\mathrm{CB}_{1} \mathrm{R}$ is expressed throughout enteric nervous system cholinergic neurons, ascending and longitudinal muscle interneurons, and intrinsic primary afferent neurons $[20,45] . \mathrm{CB}_{1} \mathrm{R}$ is also expressed within intestinal mucosa enteroendocrine cells and enterocytes $[45,47] . \mathrm{CB}_{2} \mathrm{R}$ is also expressed on enterocytes as well as on neurons in the enteric nervous system $[48,49]$.

Functionally, both $\mathrm{CB}_{1} \mathrm{R}$ and $\mathrm{CB}_{2} \mathrm{R}$ are involved in the physiologic control of the GI tract. Activation of $\mathrm{CB}_{1} \mathrm{R}$ generally leads to reduction of intestinal motility, inhibition of gastric acid secretion, and decreases the tone of the lower esophageal sphincter [20,
48]. $\mathrm{CB}_{1} \mathrm{R}$ has also been implicated in epithelial barrier control and interactions with the gut microbiome [22]. One proposed mechanism for the ECS-mediated increase in gut permeability is through the modulation of circulating levels of microbial lipopolysaccharide (LPS), a gram-negative bacteria endotoxin [50]. Support for this hypothesis is provided by examination of $\mathrm{CB}_{1} \mathrm{R}$ and $\mathrm{CB}_{2} \mathrm{R}$ in rodent models assessing gut barrier permeability [50]. Specifically, in the presence of $\mathrm{CB}_{1} \mathrm{R}$ antagonist (SR141716A), LPS levels have been shown to be reduced in the context of improved gut barrier function and decreased gut permeability. Conversely, application of the $\mathrm{CB}_{1} \mathrm{R}$ agonist (HU-210) has been associated with increased levels of circulating plasma LPS [50]. Additionally, the administration of a $\mathrm{CB}_{2} \mathrm{R}$ agonist (JWH-133) reduces LPS-mediated GI effects (e.g., motility), suggesting that it works in opposition to $\mathrm{CB}_{1} \mathrm{R}$, particularly during inflammatory states [51]. $\mathrm{CB}_{2} \mathrm{R}$ is also frequently expressed on immune cells, and their stimulation appears to facilitate suppression of immune system activity and inflammation [45]. Finally, there is evidence that activation of $\mathrm{CB}_{2} \mathrm{R}$ can reduce visceral sensitivity and pain $[48,52,53]$. Additionally, endocannabinoids AEA and 2-AG and the inhibition of their degradative enzymes FAAH and MGL, respectively, also enhance gut permeability and inhibit intestinal motility [54-60].

\section{Cannabinoid Signaling in Visceral Pain}

Direct Impacts on Visceral Pain Perception

Together, animal and human studies support the role of the ECS in the direct modulation of visceral pain pathways. As previously described, $\mathrm{CB}_{1} \mathrm{R}$ and $\mathrm{CB}_{2} \mathrm{R}$ are expressed on peripheral and central structures which influence sensory function, including extrinsic primary afferent neurons innervating the gut [61], neurons within the spinal cord [62], and regions of the brain directly associated with pain perception. This includes the periaqueductal gray and the rostral ventromedial medulla, which appear to provide key descending inhibitory input to nociceptive neurons within the spinal cord [62-65]. Of note, $\mathrm{CB}_{1} \mathrm{R}$ agonists in either the periaqueductal gray or the rostral ventromedial medulla induce analgesic effects [62]. In rodent models of visceral pain, $\mathrm{CB}_{1} \mathrm{R}$ and $\mathrm{CB}_{2} \mathrm{R}$ agonists usually induce analgesic effects $[52,53,66]$. Increasing availability of these endocannabinoid agonists, through genetic knockout or pharmacologic inhibition of FAAH and/or MAGL, also diminishes visceral pain perception in rodent models $[67,68]$, while antagonists and/or genetic knockouts of $\mathrm{CB}_{1} \mathrm{R} / \mathrm{CB}_{2} \mathrm{R}$ tend to induce hyperalgesic states $[66,69]$. For example, in human studies, synthetic THC (Dronabinol) generally induced analgesic effects and increased pain tolerance $[70,71]$. However, the analgesic effects were dependent on the clinical scenario (i.e., not effective in irritable bowel syndrome $[72,73]$, pancreatitis $[74,75]$, or postoperative pain $[75,76])$.

\section{Indirect Impacts on Visceral Pain Perception}

There are also numerous other pathways through which endocannabinoids have the potential to influence visceral pain sensation. The most obvious example of this in the setting of IBD relates to the impact that these agents have on gut inflammation (which we will discuss in following section). In a related manner, cannabinoid signaling elements have been shown to affect the GI microbiome (a significant potential determinant of IBD-associated inflammatory activity and abdominal pain) [12]. Interestingly, a rodent model treated with probiotic strains of Lactobacillus had a reduction in visceral sensitivity and an upregulation of $\mathrm{CB}_{2} \mathrm{R}$ and 
$\mu$-opioid receptors in intestinal epithelium [77]. These reductions in visceral sensation were likely mediated by the $\mathrm{CB}_{2} \mathrm{R}$, given the analgesic effects were reversed in the setting of $\mathrm{CB}_{2} \mathrm{R}$ antagonists [77].

\section{Influence of the ECS in IBD}

In addition to the analgesic effects described above, there are several mechanisms through which $\mathrm{CB}_{1} \mathrm{R}$ and $\mathrm{CB}_{2} \mathrm{R}$ may serve a protective role and provide novel targets for pharmacologic modulation in IBD [54]. One report found elevated concentrations of $\mathrm{CB}_{1} \mathrm{R}$ but no significant difference in $\mathrm{CB}_{2} \mathrm{R}$ in inflamed mucosa compared to uninflamed mucosa in IBD patients [78]. However, there is no consensus regarding the relative changes in expression of $\mathrm{CB}_{1} \mathrm{R}$ and $\mathrm{CB}_{2} \mathrm{R}$ in the setting of IBD $[7,55]$. The pathophysiology of IBD involves increased gut permeability, particularly in the setting of active disease inflammation [79]. As previously discussed, there is emerging evidence suggesting that gut epithelial permeability is under regulatory control by the ECS and microbiota, and thus a potential target for pharmaceutical therapy [55].

\section{ECS Impact on Animal Models of IBD}

In rodent models of $I B D, C_{1} R$ and $\mathrm{CB}_{2} \mathrm{R}$ agonists reduced the gut mucosa inflammation and improved IBD-related symptoms $[30,80]$. Similarly, increasing availability of the endogenous $C_{1} R$ and $\mathrm{CB}_{2} \mathrm{R}$ agonist, through genetic knockout or pharmacologicmediated inhibition of the metabolism of AEA, reduced gut mucosa inflammation in rodent models of IBD [81, 82]. Conversely, pretreatment with $\mathrm{CB}_{1} \mathrm{R}$ and $\mathrm{CB}_{2} \mathrm{R}$ antagonists and/or genetic knockouts of these receptors prevent their protective effects on disease inflammation and even induce colitis in rodent IBD models $[80,81]$. However, although the data from IBD rodent models have been promising, this has not translated to modulation of disease-related inflammation in human clinical trials studies [13-16].

\section{ECS Impact on Patients with IBD}

The use of Cannabis or Cannabis derivatives is common among patients with IBD for symptomatic relief, often specifically for abdominal pain relief $[6,9,83,84]$. The initial small cohort studies for Cannabis use (variable forms of consumption) in IBD were promising as its use was associated with symptom relief, improved health-related quality of life, and reduction of alternative analgesic medications in patients with IBD $[8,15]$. However, although the subsequent larger studies also found that Cannabis use (variable forms of consumption) was associated with symptom improvement $[9,13], 1$ report found an increased risk of surgery in those patients [13]. The clinical trials conducted thus far have not demonstrated any objective changes in disease markers of inflammation. Thus far, there have only been 3 relatively small placebo-controlled studies with Cannabis use in active CD. Notably, 2 of these reports demonstrated an improvement in IBD-related symptoms $[13,16]$. A report on the effects of long-term Cannabis use (variable forms of consumption) in IBD found patients had an improvement in IBD-related symptoms, decreased use of alternative medications, and weight gain [17]. Interestingly, there were recommendations on the dosage of THC (21 mg) and CBD (170 mg) that induced a clinical response [17].

A randomized controlled trial of low-dose $(10 \mathrm{mg}$ provided twice per day) CBD in CD was reportedly well-tolerated but had no discernible impact on disease activity [14]. A follow-up randomized controlled trial in mild to moderate UC (refractory to 5-aminosalicylic acid) using a higher dose of CBD oil (50-250 mg twice per day) induced symptomatic improvement (including reduced abdominal pain) [85]. Notably, there was still no overt impact on CD inflammatory activity, and fewer patients were able to tolerate the increased dose of CBD [85]. Of note, there is an ongoing phase II placebo-controlled clinical trial in CD using an even higher dose of CBD (300 mg) [86]. A separate dose-escalation trial of CBD in Parkinson's disease (utilizing a maximum dose of $20-25 \mathrm{mg} / \mathrm{kg} /$ day for $10-15$ days in 15 patients) found that it was associated with increased liver enzymes in this population [87]. In summary, at the present time, clinical data relating to use of Cannabis and its derivatives in IBD is still limited. However, the studies currently available demonstrate significant impacts on symptom perception (e.g., abdominal pain), but not on intestinal inflammation or disease course.

\section{Indirect Influences on Visceral Pain Perception}

In addition to the effects the ECS has on visceral pain perception described above, it also exerts indirect influences on pain perception, including within the GI system.

\section{Psychiatric Effects of Endocannabinoids}

Cannabis and many of its derivatives have been associated with a wide array of positive and negative psychiatric effects, many of which can influence abdominal pain perception. Patient responses to Cannabis consumption vary considerably depending on several factors, including the exact form and subtype consumed, the associated dosage and frequency, and clinical and epidemiological features of the individual [88]. In the acute setting, individuals consuming Cannabis may describe sensations of euphoria and relaxation or panic, anxiety, depression, and even psychosis [89, 90]. THC, a nonselective partial agonist of $\mathrm{CB}_{1} \mathrm{R}$ and $\mathrm{CB}_{2} \mathrm{R}$, is the primary cannabinoid component that mediates these effects $[27,90]$. In rodent models, the administration of THC induced dose-dependent catalepsy, which correlates with psychotropic effects in humans [90]. Additionally, quantitative bioassays of THC-induced sedation, ptosis, and body sag in monkeys and static ataxia in dogs, which in combination with human trials confirms THC mediates the psychotropic effects of Cannabis [91]. These symptoms all have the capability of influencing patient pain experience. Colorectal distension rodent models, widely accepted laboratory assessments of visceral pain, identified the $\mathrm{CB}_{1} \mathrm{R}$ and $\mathrm{CB}_{2} \mathrm{R}$ agonists reduce pain, while antagonism increases visceral pain sensation [92-94]. There were, however, mixed reports whether the effects were mediated with $C_{1} R$ alone [66] or both $C_{1} R$ and $C B_{2} R$ $[92,93]$. Regardless of the promising data in animal models, THC showed no impact [72] or even increased pain sensation [95] after colorectal distension in patients with irritable bowel syndrome or chronic pancreatitis [75]. In the case of IBS, the psychotropic side effect of increased awareness was hypothesized to contribute to the worsened pain symptoms [95]. Similarly, the psychiatric effects of Cannabis may induce a paradoxical effect in the setting abdominal pain. THC has shown efficacy in pain reduction in other clinical scenarios, such as neuropathic pain in multiple sclerosis [96] or chronic cancer-related pain when combined with CBD [97]. With chronic Cannabis use, it is also possible to develop signs of dependency and withdrawal [98-100], and this has been associated with an increased risk of developing substance use disorders [101, 102], many of which may also influence pain perception. 
ECS Impact on GI Motility

Cannabinoid effects on gut motility may also have a significant influence on visceral pain perception. Altered states of gut motility can be associated with abdominal discomfort and other related symptoms [103]. Animal models demonstrate that Cannabis exposure generally leads to reductions in GI motility throughout the GI tract [104]. These effects appear to be primarily mediated by an inhibition of acetylcholine release, which leads to reduced peristalsis and smooth muscle contractility [105]. $\mathrm{CB}_{1} \mathrm{R}$ agonists have been found to reduce GI motility, while $\mathrm{CB}_{1} \mathrm{R}$ antagonists increased GI motility [106]. $\mathrm{CB}_{2} \mathrm{R}$ has also been implicated in the reduction of GI motility, particularly during inflammatory states [107]. In human studies, the administration of THC, a nonselective agonist of $\mathrm{CB}_{1} \mathrm{R}$ and $\mathrm{CB}_{2} \mathrm{R}$, has been associated with a reduction in GI motility and constipation [108]. In a rodent model of croton oil-induced intestinal inflammation, the primary nonpsychoactive cannabinoid, CBD, also inhibited GI motility [109]. Importantly, CBD only reduced gut motility in the setting of gut inflammation and not under normal conditions [109]. Additionally, IBD patients have reported a Cannabis-mediated improvement in diarrhea and abdominal pain/discomfort in several studies [6, 9, 13]. Thus, Cannabis-mediated effects on GI motility could be an important influence on abdominal pain experience of these individuals.

ECS Impact on Nausea

Perceptions of pain and nausea can be closely linked to 1 another $[110,111]$. Cannabinoids have a complicated influence on perception of nausea and, in turn, may influence abdominal pain perception in a related manner. In animal (rodent) models, administration of cannabinoids or FAAH inhibitors reduce signs of nausea, while use of cannabinoid antagonists resulted in demonstration of nausea $[112,113]$. Similarly, cannabinoids reduced symptoms of vomiting in several animal models of cisplatin or opioid-induced vomiting (e.g., cats [114], pigeons [115, 116], ferrets $[117,118]$, and least shrews [112], among others [119]). These antiemetic effects have been directly attributed to $\mathrm{CB}_{1}$ Rs found in vomiting control centers in the dorsal vagal complex, including the area postrema, nucleus solitary tract, and dorsal motor nucleus of the vagus $[112,118,120]$. There are also peripheral mechanisms involved through THC-mediated inhibition of 5-hydroxytryptophan-induced emesis [120].

In the clinical setting, there is evidence that cannabinoids can be helpful for acute reduction of nausea associated with a variety of conditions $[112,121]$. In a recent study, synthetic THC (Dronabinol) had similar efficacy for the treatment of chemotherapy-induced nausea and vomiting in comparison to ondansetron, 1 of the most commonly used antiemetic agents [122]. In a separate study in patients exhibiting chemotherapy-induced nausea and vomiting, there was reduction of delayed nausea and vomiting when combining THC/CBD with ondansetron [123]. There are also reports from human trials in which $\mathrm{CB}_{1} \mathrm{R}$ antagonists induced nausea and emesis [124, 125]. Alternatively, however, long-term users can develop a paradoxical and debilitating effect in which they experience recurrent or persistent nausea after exposure to cannabinoids called cannabis hyperemesis syndrome [126]. Although the mechanism is unknown, Cannabis cessation appears to help improve these symptoms in this circumstance.

Cannabis for Pain Management in IBD

\section{Current Considerations and Challenges}

Providers need to keep in mind several significant issues when cannabinoids are utilized or are being considered for use in a clinical setting. First, there are a variety of potential legal hurdles that limit Cannabis and cannabinoid clinical use and research in the USA [127]. Although there is a trend in the USA toward increasing availability of medicinal Cannabis (an estimated 69\% of residents reside within a state with either medicinal Cannabis or recreational marijuana as of November 2020 [4]), there is no federal legislation permitting its medicinal use at a national level [127]. Cannabis remains a Schedule I substance in the USA. Second, biomedical investigators face a variety of legal and administrative restrictions when considering research relating to Cannabis/cannabinoids [127]. There are currently significant limitations in regard to potential suppliers and on the amount and type of Cannabis and/or its derivatives that are available to investigators. As it is illegal at the federal level, Cannabis (medicinal or otherwise) also cannot be transported across state lines. Third, negative societal stigmatization of Cannabis and cannabinoid use remains a significant issue. Individuals perceive that their peers and/or potential employers view them negatively $[128,129]$ and may be less willing to utilize these agents.

Additionally, there are a variety of side effects that have been associated with Cannabis use. One primary limitation involves the psychoactive effects. Cannabis consumption has been associated with decreased motivation and reaction time, as well as alterations in executive function [130]. In certain circumstances, Cannabis may also induce auditory or visual hallucinations, and increase risk for a variety of psychiatric illnesses [131]. Adolescents are at increased risk for the negative side effects of chronic use, including increased risk of schizophrenia later in life and decreased intelligence quotient [131]. Chronic Cannabis use can also lead to problematic GI symptoms, such as nausea. These adverse issues are likely related to particular constituents of Cannabis (e.g., THC). As a result, for years there has been great interest in separating out and testing various cannabinoid elements.

One of the biggest barriers, however, is a current lack of knowledge relating to Cannabis and its derivatives. The legal and societal barriers described above have significantly limited the degree to these agents have been studied in the clinical setting in the USA. While Cannabis holds significant potential promise in a variety of clinical

Med Cannabis Cannabinoids 2021;4:97-106 
applications, we clearly need to learn much more about it and its components in order to determine their true efficacy and safety in each setting.

\section{Conclusion and Future Considerations}

Cannabis and its derivatives have great therapeutic potential in the setting of IBD, particularly as potential treatments for associated frequent and problematic symptoms, including abdominal pain, and pain-modifying issues such as diarrhea and nausea. An increasing number of patients have access to Cannabis and cannabinoid agents, and it is very common for individuals with IBD to inquire about the potential utility of these agents for managing their disease. As we have reviewed here, a wide variety and number of animal and human studies have demonstrated not only the positive impact that cannabinoids can have in this context but also the multitude of pathways these agents may work through to induce their analgesic effects. However, relatively few studies have been undertaken in humans to evaluate this potential, particularly when considering select cannabinoid signaling elements. It is also unclear whether cannabinoids will be helpful to mitigate intestinal inflammation in humans, though clinical studies assessing for this in IBD are still relatively scarce.

It is clear that further study is required (particularly in the clinical setting) in order to determine the true potential of Cannabis and its components to manage IBD and its symptoms. Future research considerations should focus more specifically on derivatives of Cannabis and elements of the endocannabinoid signaling system, with the goal of developing and testing therapies that minimize psychotropic side effects, while optimizing analgesia. While evaluating separate cannabinoid components, investigators will also need to consider the potential interplay between these therapies and other medications that study subjects are receiving, as endocannabinoids mediate a variety of sensory pathways and signaling systems. Finally, given the myriad pathophysiological and clinical differences among them, there should also be careful consideration for evaluating these agents in different, carefully phenotyped forms of IBD, including in both CD and UC.

\section{Acknowledgments}

The National Institutes of Health and National Institute of Diabetes and Digestive and Kidney Diseases (R01DK122364) (MDC), the Peter and Marsha Carlino Early Career Professorship in IBD (MDC), and the Margot E. Walrath Career Development Professorship in Gastroenterology (MDC).

\section{Conflict of Interest Statement}

The authors have no conflicts of interest to declare.

\section{Author Contributions}

K.B. performed a comprehensive literature review and helped to write and edit the manuscript. W.R.-K. helped to write and review the manuscript. S.D. helped to write and edit the manuscript. K.V. helped to conceptualize this project, write, and review the manuscript. M.C. developed the primary concept behind this manuscript, performed a comprehensive literature review, and helped to write and review the manuscript.

\section{References}

1 Leung L. Cannabis and its derivatives: review of medical use. J Am Board Fam Med. 2011; 24(4):452-62.

2 Picardo S, Kaplan GG, Sharkey KA, Seow CH. Insights into the role of cannabis in the management of inflammatory bowel disease. Therap Adv Gastroenterol. 2019;12: 1756284819870977.

3 Alharbi YN. Current legal status of medical marijuana and cannabidiol in the United States. Epilepsy Behav. 2020;112:107452.

4 Carnevale Associate LLC. Status of state marijuana legalization: November 2020 carnevale associates LLC: carnevale associates LLC policy \& issue briefs. 2020. Available from: https: //www.carnevaleassociates.com/our-work/ status-of-state-marijuana-legalization---november-2020.html.

5 Levinsohn EA, Hill KP. Clinical uses of cannabis and cannabinoids in the United States. J Neurol Sci. 2020;411:116717.

6 Lal S, Prasad N, Ryan M, Tangri S, Silverberg MS, Gordon A, et al. Cannabis use amongst patients with inflammatory bowel disease. Eur J Gastroenterol Hepatol. 2011;23(10): 891-6.

7 Swaminath A, Berlin EP, Cheifetz A, Hoffenberg E, Kinnucan J, Wingate L, et al. The role of cannabis in the management of inflammatory bowel disease: a review of clinical, scientific, and regulatory information. Inflamm Bowel Dis. 2019;25(3):427-35.
8 Lahat A, Lang A, Ben-Horin S. Impact of cannabis treatment on the quality of life, weight and clinical disease activity in inflammatory bowel disease patients: a pilot prospective study. Digestion. 2012;85(1):1-8.

9 Ravikoff Allegretti J, Courtwright A, Lucci M, Korzenik JR, Levine J. Marijuana use patterns among patients with inflammatory bowel disease. Inflamm Bowel Dis. 2013;19(13):280914.

10 Garcia-Planella E, Marin L, Domenech E, Bernal I, Manosa M, Zabana Y, et al. [use of complementary and alternative medicine and drug abuse in patients with inflammatory bowel disease]. Med Clin. 2007;128(2): 45-8. 
11 Ahmed W, Katz S. Therapeutic use of cannabis in inflammatory bowel disease. Gastroenterol Hepatol. 2016;12(11):668-79.

12 Sharkey KA, Wiley JW. The role of the endocannabinoid system in the brain-gut axis. Gastroenterology. 2016;151(2):252-66.

13 Storr M, Devlin S, Kaplan GG, Panaccione R, Andrews CN. Cannabis use provides symptom relief in patients with inflammatory bowel disease but is associated with worse disease prognosis in patients with Crohn's disease. Inflamm Bowel Dis. 2014;20(3):472-80.

14 Naftali T, Mechulam R, Marii A, Gabay G, Stein A, Bronshtain M, et al. Low-dose cannabidiol is safe but not effective in the treatment for Crohn's disease, a randomized controlled trial. Dig Dis Sci. 2017;62(6):1615-20.

15 Naftali T, Lev LB, Yablecovitch D, Yablekovitz D, Half E, Konikoff FM. Treatment of Crohn's disease with cannabis: an observational study. Isr Med Assoc J. 2011;13(8): $455-8$.

16 Naftali T, Bar-Lev Schleider L, Dotan I, Lansky EP, Sklerovsky Benjaminov F, Konikoff FM. Cannabis induces a clinical response in patients with Crohn's disease: a prospective placebo-controlled study. Clin Gastroenterol Hepatol. 2013;11(10):1276-e1.

17 Naftali T, Bar-Lev Schleider L, Sklerovsky Benjaminov F, Lish I, Konikoff FM, Ringel Y. Medical cannabis for inflammatory bowel disease: real-life experience of mode of consumption and assessment of side-effects. Eur J Gastroenterol Hepatol. 2019;31(11):137681.

18 Castillo PE, Younts TJ, Chávez AE, Hashimotodani Y. Endocannabinoid signaling and synaptic function. Neuron. 2012;76(1):70-81.

19 Taschler U, Hasenoehrl C, Storr M, Schicho R. Cannabinoid receptors in regulating the GI tract: experimental evidence and therapeutic relevance. Handb Exp Pharmacol. 2017;239: 343-62.

20 Galligan JJ. Cannabinoid signalling in the enteric nervous system. Neurogastroenterol Motil. 2009;21(9):899-902.

21 Pertwee RG, Howlett AC, Abood ME, Alexander SP, Di Marzo V, Elphick MR, et al. International union of basic and clinical pharmacology. LXXIX. Cannabinoid receptors and their ligands: beyond $\mathrm{CB}(1)$ and $\mathrm{CB}(2)$. Pharmacol Rev. 2010;62(4):588-631.

22 Cani PD, Plovier H, Van Hul M, Geurts L, Delzenne NM, Druart C, et al. Endocannabinoids-at the crossroads between the gut microbiota and host metabolism. Nat Rev Endocrinol. 2016;12(3):133-43.

23 Zou S, Kumar U. Cannabinoid receptors and the endocannabinoid system: signaling and function in the central nervous system. Int J Mol Sci. 2018;19(3):833.

24 Sugiura T, Waku K. 2-arachidonoylglycerol and the cannabinoid receptors. Chem Phys Lipids. 2000;108(1-2):89-106.
25 Glass M, Northup JK. Agonist selective regulation of $\mathrm{G}$ proteins by cannabinoid $\mathrm{CB}(1)$ and $\mathrm{CB}(2)$ receptors. Mol Pharmacol. 1999; 56(6):1362-9.

26 Svízenská I, Dubový P, Sulcová A. Cannabinoid receptors 1 and 2 (CB1 and $\mathrm{CB} 2$ ), their distribution, ligands and functional involvement in nervous system structures-a short review. Pharmacol Biochem Behav. 2008;90(4):501-11.

27 Alhouayek M, Muccioli GG. The endocannabinoid system in inflammatory bowel diseases: from pathophysiology to therapeutic opportunity. Trends Mol Med. 2012;18(10): 615-25.

28 Cluny NL, Keenan CM, Duncan M, Fox A, Lutz B, Sharkey KA. Naphthalen-1-yl-(4-pentyloxynaphthalen-1-yl) methanone (SAB378), a peripherally restricted cannabinoid CB1/CB2 receptor agonist, inhibits gastrointestinal motility but has no effect on experimental colitis in mice. J Pharmacol Exp Ther. 2010;334(3):973-80.

29 Hanus L, Abu-Lafi S, Fride E, Breuer A, Vogel $Z$, Shalev DE, et al. 2-arachidonyl glyceryl ether, an endogenous agonist of the cannabinoid CB1 receptor. Proc Natl Acad Sci U S A. 2001;98(7):3662-5

30 Kimball ES, Schneider CR, Wallace NH, Hornby PJ. Agonists of cannabinoid receptor 1 and 2 inhibit experimental colitis induced by oil of mustard and by dextran sulfate sodium. Am J Physiol Gastrointest Liver Physiol. 2006;291(2):G364-71.

31 Rinaldi-Carmona $M$, Barth F, Héaulme $M$, Shire D, Calandra B, Congy C, et al. SR141716A, a potent and selective antagonist of the brain cannabinoid receptor. FEBS Lett. 1994;350(2-3):240-4.

32 Lange JH, Kruse CG. Keynote review: medicinal chemistry strategies to CB1 cannabinoid receptor antagonists. Drug Discov Today. 2005;10(10):693-702.

33 Izzo AA. The cannabinoid CB2 receptor: a good friend in the gut. Neurogastroenterol Motil. 2007;19(9):704-8

34 Leinwand KL, Jones AA, Huang RH, Jedlicka P, Kao DJ, de Zoeten EF, et al. Cannabinoid receptor-2 ameliorates inflammation in murine model of Crohn's disease. J Crohns Colitis. 2017;11(11):1369-80

35 Schlicker E, Kathmann M. Modulation of transmitter release via presynaptic cannabinoid receptors. Trends Pharmacol Sci. 2001; 22(11):565-72.

36 Joshi N, Onaivi ES. Endocannabinoid system components: overview and tissue distribution. In: Bukiya AN, editor. Recent advances in cannabinoid physiology and pathology. Cham, Switzerland: Springer; 2019. Vol. 1162; p. 1-12.

37 Ahn K, Smith SE, Liimatta MB, Beidler D, Sadagopan N, Dudley DT, et al. Mechanistic and pharmacological characterization of PF04457845: a highly potent and selective fatty acid amide hydrolase inhibitor that reduces inflammatory and noninflammatory pain. J Pharmacol Exp Ther. 2011;338(1):114-24.
38 Piomelli D, Tarzia G, Duranti A, Tontini A, Mor M, Compton TR, et al. Pharmacological profile of the selective FAAH inhibitor KDS4103 (URB597). CNS Drug Rev. 2006;12(1): 21-38.

39 Ahn K, Johnson DS, Mileni M, Beidler D, Long JZ, McKinney MK, et al. Discovery and characterization of a highly selective FAAH inhibitor that reduces inflammatory pain. Chem Biol. 2009;16(4):411-20.

40 Kinsey SG, Wise LE, Ramesh D, Abdullah R Selley DE, Cravatt BF, et al. Repeated lowdose administration of the monoacylglycerol lipase inhibitor JZL184 retains cannabinoid receptor type 1-mediated antinociceptive and gastroprotective effects. J Pharmacol Exp Ther. 2013;345(3):492-501.

41 Chang JW, Niphakis MJ, Lum KM, Cognetta $A B$, Wang C, Matthews ML, et al. Highly selective inhibitors of monoacylglycerol lipase bearing a reactive group that is bioisosteric with endocannabinoid substrates. Chem Biol. 2012;19(5):579-88.

42 Chang JW, Cognetta AB 3rd, Niphakis MJ, Cravatt BF. Proteome-wide reactivity profiling identifies diverse carbamate chemotypes tuned for serine hydrolase inhibition. ACS Chem Biol. 2013;8(7):1590-9.

43 Aaltonen N, Savinainen JR, Ribas CR, Rönkkö J, Kuusisto A, Korhonen J, et al. Piperazine and piperidine triazole ureas as ultrapotent and highly selective inhibitors of monoacylglycerol lipase. Chem Biol. 2013;20(3):37990.

44 Niphakis MJ, Cognetta AB, Chang JW, Buczynski MW, Parsons LH, Byrne F, et al. Evaluation of NHS carbamates as a potent and selective class of endocannabinoid hydrolase inhibitors. ACS Chem Neurosci. 2013;4(9): 1322-32.

45 Maccarrone M, Bab I, Bíró T, Cabral GA, Dey SK, Di Marzo V, et al. Endocannabinoid signaling at the periphery: 50 years after THC. Trends Pharmacol Sci. 2015;36(5):277-96.

46 Wright K, Rooney N, Feeney M, Tate J, Robertson D, Welham M, et al. Differential expression of cannabinoid receptors in the human colon: cannabinoids promote epithelial wound healing. Gastroenterology. 2005; 129(2):437-53.

47 Toschi A, Galiazzo G, Piva A, Tagliavia C, Mazzuoli-Weber G, Chiocchetti R, et al. Cannabinoid and cannabinoid-related receptors in the myenteric plexus of the porcine ileum. Animals. 2021;11(2):263.

48 Wright KL, Duncan M, Sharkey KA. Cannabinoid CB2 receptors in the gastrointestinal tract: a regulatory system in states of inflammation. Br J Pharmacol. 2008;153(2):263-70.

49 Duncan M, Mouihate A, Mackie K, Keenan CM, Buckley NE, Davison JS, et al. Cannabinoid CB2 receptors in the enteric nervous system modulate gastrointestinal contractility in lipopolysaccharide-treated rats. Am J Physiol Gastrointest Liver Physiol. 2008;295(1):G7887. 
50 Muccioli GG, Naslain D, Bäckhed F, Reigstad CS, Lambert DM, Delzenne NM, et al. The endocannabinoid system links gut microbiota to adipogenesis. Mol Syst Biol. 2010;6(1):392.

51 Mathison R, Ho W, Pittman QJ, Davison JS, Sharkey KA. Effects of cannabinoid receptor- 2 activation on accelerated gastrointestinal transit in lipopolysaccharide-treated rats. Br J Pharmacol. 2004;142(8):1247-54.

52 Jaggar SI, Hasnie FS, Sellaturay S, Rice AS The anti-hyperalgesic actions of the cannabinoid anandamide and the putative $\mathrm{CB} 2$ receptor agonist palmitoylethanolamide in visceral and somatic inflammatory pain. Pain. 1998; 76(1-2):189-99.

53 Zhang L, Kline RH, McNearney TA, Johnson MP, Westlund KN. Cannabinoid receptor 2 agonist attenuates pain related behavior in rats with chronic alcohol/high fat diet induced pancreatitis. Mol Pain. 2014;10:66.

54 DiPatrizio NV. Endocannabinoids in the gut. Cannabis Cannabinoid Res. 2016;1(1):67-77.

55 Izzo AA, Sharkey KA. Cannabinoids and the gut: new developments and emerging concepts. Pharmacol Ther. 2010;126(1):21-38.

56 Karwad MA, Couch DG, Theophilidou E, Sarmad S, Barrett DA, Larvin M, et al. The role of CB1 in intestinal permeability and inflammation. Faseb J. 2017;31(8):3267-77.

57 Karwad MA, Macpherson T, Wang B, Theophilidou E, Sarmad S, Barrett DA, et al. Oleoylethanolamine and palmitoylethanolamine modulate intestinal permeability in vitro via TRPV1 and PPARa. Faseb J. 2017; 31(2):469-81

58 Duncan M, Thomas AD, Cluny NL, Patel A, Patel KD, Lutz B, et al. Distribution and function of monoacylglycerol lipase in the gastrointestinal tract. Am J Physiol Gastrointest Liver Physiol. 2008;295(6):G1255-65.

59 Little TJ, Cvijanovic N, DiPatrizio NV, Argueta DA, Rayner CK, Feinle-Bisset C, et al. Plasma endocannabinoid levels in lean, overweight, and obese humans: relationships to intestinal permeability markers, inflammation, and incretin secretion. Am J Physiol Endocrinol Metab. 2018;315(4):E489-E95.

60 Bashashati M, Storr MA, Nikas SP, Wood JT, Godlewski G, Liu J, et al. Inhibiting fatty acid amide hydrolase normalizes endotoxin-induced enhanced gastrointestinal motility in mice. Br J Pharmacol. 2012;165(5):1556-71.

61 Rice AS, Farquhar-Smith WP, Nagy I. Endocannabinoids and pain: spinal and peripheral analgesia in inflammation and neuropathy. Prostaglandins Leukot Essent Fatty Acids. 2002;66(2-3):243-56.

62 Wilson RI, Nicoll RA. Endocannabinoid signaling in the brain. Science. 2002;296(5568): 678-82.

63 Van Sickle MD, Duncan M, Kingsley PJ, Mouihate A, Urbani P, Mackie K, et al. Identification and functional characterization of brainstem cannabinoid CB2 receptors. Science. 2005;310(5746):329-32.
64 Gong JP, Onaivi ES, Ishiguro H, Liu QR, Tagliaferro PA, Brusco A, et al. Cannabinoid CB2 receptors: immunohistochemical localization in rat brain. Brain Res. 2006;1071(1): 10-23.

65 Stempel AV, Stumpf A, Zhang HY, Özdoğan T, Pannasch U, Theis AK, et al. Cannabinoid type 2 receptors mediate a cell type-specific plasticity in the hippocampus. Neuron. 2016; 90(4):795-809.

66 Brusberg M, Arvidsson S, Kang D, Larsson H, Lindström E, Martinez V. CB1 receptors mediate the analgesic effects of cannabinoids on colorectal distension-induced visceral pain in rodents. J Neurosci. 2009;29(5):1554-64.

67 Lichtman AH, Naidu PS, Booker L, Boger DL, Cravatt BF. Targeting FAAH and COX to treat visceral pain. FASEB J. 2008;22:1125.12.

68 Sakin YS, Dogrul A, Ilkaya F, Seyrek M, Ulas $\mathrm{UH}$, Gulsen M, et al. The effect of FAAH, MAGL, and dual FAAH/MAGL inhibition on inflammatory and colorectal distension-induced visceral pain models in rodents. Neurogastroenterol Motil. 2015;27(7):936-44.

69 Valenzano KJ, Tafesse L, Lee G, Harrison JE, Boulet JM, Gottshall SL, et al. Pharmacological and pharmacokinetic characterization of the cannabinoid receptor 2 agonist, GW405833, utilizing rodent models of acute and chronic pain, anxiety, ataxia and catalepsy. Neuropharmacology. 2005;48(5):658-72.

70 Narang S, Gibson D, Wasan AD, Ross EL, Michna E, Nedeljkovic SS, et al. Efficacy of dronabinol as an adjuvant treatment for chronic pain patients on opioid therapy. J Pain. 2008;9(3):254-64.

71 Malik Z, Bayman L, Valestine J, Schey R. Dronabinol increases pain threshold in noncardiac chest pain: a double-blind placebocontrolled trial. Am J Gastroenterol. 2014; 109:S32.Acg auxiliary award-trainee: 93.

72 Klooker TK, Leliefeld KE, Van Den Wijngaard RM, Boeckxstaens GE. The cannabinoid receptor agonist delta-9-tetrahydrocannabinol does not affect visceral sensitivity to rectal distension in healthy volunteers and ibs patients. Neurogastroenterol Motil. 2011; 23(1):30-5; e2.e2

73 Wong BS, Camilleri M, Busciglio I, Carlson P, Szarka LA, Burton D, et al. Pharmacogenetic trial of a cannabinoid agonist shows reduced fasting colonic motility in patients with nonconstipated irritable bowel syndrome. Gastroenterology. 2011;141(5):1638-7.

74 de Vries M, Van Rijckevorsel DC, Vissers KC Wilder-Smith OH, Van Goor H. Single dose delta-9-tetrahydrocannabinol in chronic pancreatitis patients: analgesic efficacy, pharmacokinetics and tolerability. Br J Clin Pharmacol. 2016;81(3):525-37.

75 de Vries M, van Rijckevorsel DCM, Vissers KCP, Wilder-Smith OHG, van Goor H. Tetrahydrocannabinol does not reduce pain in patients with chronic abdominal pain in a phase 2 placebo-controlled study. Clin Gastroenterol Hepatol. 2017;15(7):1079-1086.e4.
76 Buggy DJ, Toogood L, Maric S, Sharpe P, Lambert DG, Rowbotham DJ. Lack of analgesic efficacy of oral delta-9-tetrahydrocannabinol in postoperative pain. Pain. 2003;106(12):169-72.

77 Rousseaux C, Thuru X, Gelot A, Barnich N, Neut C, Dubuquoy L, et al. Lactobacillus acidophilus modulates intestinal pain and induces opioid and cannabinoid receptors. Nat Med. 2007;13(1):35-7.

78 Di Sabatino A, Battista N, Biancheri P, Rapino C, Rovedatti L, Astarita G, et al. The endogenous cannabinoid system in the gut of patients with inflammatory bowel disease. $\mathrm{Mu}$ cosal Immunol. 2011;4(5):574-83.

79 McGuckin MA, Eri R, Simms LA, Florin TH, Radford-Smith G. Intestinal barrier dysfunction in inflammatory bowel diseases. Inflamm Bowel Dis. 2009;15(1):100-13.

80 Storr MA, Keenan CM, Zhang H, Patel KD, Makriyannis A, Sharkey KA. Activation of the cannabinoid 2 receptor (CB2) protects against experimental colitis. Inflamm Bowel Dis. 2009;15(11):1678-85.

81 Storr MA, Keenan CM, Emmerdinger D, Zhang H, Yüce B, Sibaev A, et al. Targeting endocannabinoid degradation protects against experimental colitis in mice: involvement of CB1 and CB2 receptors. J Mol Med. 2008;86(8):925-36.

82 Massa F, Marsicano G, Hermann H, Cannich A, Monory K, Cravatt BF, et al. The endogenous cannabinoid system protects against colonic inflammation. J Clin Invest. 2004; 113(8):1202-9.

83 Phatak UP, Rojas-Velasquez D, Porto A, Pashankar DS. Prevalence and patterns of marijuana use in young adults with inflammatory bowel disease. J Pediatr Gastroenterol Nutr. 2017;64(2):261-4.

84 Hoffenberg EJ, McWilliams SK, MikulichGilbertson SK, Murphy BV, Lagueux M, Robbins K, et al. Marijuana use by adolescents and young adults with inflammatory bowel disease. J Pediatr. 2018;199:99-105.

85 Irving PM, Iqbal T, Nwokolo C, Subramanian S, Bloom S, Prasad N, et al. A randomized, double-blind, placebo-controlled, parallelgroup, pilot study of cannabidiol-rich botanical extract in the symptomatic treatment of ulcerative colitis. Inflamm Bowel Dis. 2018; 24(4):714-24.

86 Stero Biotechs Ltd. A phase 2a study to evaluate the safety, tolerability and efficacy of cannabidiol as a steroid-sparing therapy in steroid-dependent crohn's disease patients. Available from: https://ClinicalTrials.gov/ show/NCT04056442 Clinical Trials.gov Identifier: NCT04056442.

87 Leehey MA, Liu Y, Hart F, Epstein C, Cook M, Sillau S, et al. Safety and tolerability of cannabidiol in Parkinson disease: an open label dose-escalation study. Cannabis Cannabinoid Res. 2020;5(4):326-36.

Bogale/Raup-Konsavage/Dalessio/Vrana/ Coates 
MacCallum CA, Russo EB. Practical considerations in medical cannabis administration and dosing. Eur J Intern Med. 2018;49:12-9.

89 Murray RM, Englund A, Abi-Dargham A, Lewis DA, Di Forti M, Davies C, et al. Cannabis-associated psychosis: neural substrate and clinical impact. Neuropharmacology. 2017;124:89-104.

90 Pertwee RG. Cannabinoid pharmacology: the first 66 years. Br J Pharmacol. 2006; 147(Suppl 1):S163-71.

91 Howlett AC, Barth F, Bonner TI, Cabral G, Casellas P, Devane WA, et al. International Union of Pharmacology. XXVII. Classification of cannabinoid receptors. Pharmacol Rev. 2002;54(2):161-202.

92 Malik Z, Baik D, Schey R. The role of cannabinoids in regulation of nausea and vomiting, and visceral pain. Curr Gastroenterol Rep. 2015;17(2):429.

93 Sanson M, Bueno L, Fioramonti J. Involvement of cannabinoid receptors in inflammatory hypersensitivity to colonic distension in rats. Neurogastroenterol Motil. 2006;18(10): 949-56.

94 Kikuchi A, Ohashi K, Sugie Y, Sugimoto H, Omura H. Pharmacological evaluation of a novel cannabinoid 2 (CB2) ligand, pf03550096, in vitro and in vivo by using a rat model of visceral hypersensitivity. J Pharmacol Sci. 2008;106(2):219-24.

95 Esfandyari T, Camilleri M, Busciglio I, Burton D, Baxter K, Zinsmeister AR. Effects of a cannabinoid receptor agonist on colonic motor and sensory functions in humans: a randomized, placebo-controlled study. Am J Physiol Gastrointest Liver Physiol. 2007; 293(1):G137-45.

96 Rog DJ, Nurmikko TJ, Friede T, Young CA. Randomized, controlled trial of cannabisbased medicine in central pain in multiple sclerosis. Neurology. 2005;65(6):812-9.

97 Johnson JR, Burnell-Nugent M, Lossignol D, Ganae-Motan ED, Potts R, Fallon MT. Multicenter, double-blind, randomized, placebo-controlled, parallel-group study of the efficacy, safety, and tolerability of THC:CBD extract and thc extract in patients with intractable cancer-related pain. J Pain Symptom Manage. 2010;39(2):167-79.

98 Lopez-Quintero C, Pérez de los Cobos J, Hasin DS, Okuda M, Wang S, Grant BF, et al. Probability and predictors of transition from first use to dependence on nicotine, alcohol, cannabis, and cocaine: results of the national epidemiologic survey on alcohol and related conditions (NESARC). Drug Alcohol Depend. 2011;115(1-2):120-30.

99 Hall W, Degenhardt L. Adverse health effects of non-medical cannabis use. Lancet. 2009;374(9698):1383-91.

100 Gorelick DA, Levin KH, Copersino ML, Heishman SJ, Liu F, Boggs DL, et al. Diagnostic criteria for cannabis withdrawal syndrome. Drug Alcohol Depend. 2012;123(13):141-7.
101 Blanco C, Hasin DS, Wall MM, Flórez-Salamanca L, Hoertel N, Wang S, et al. Cannabis use and risk of psychiatric disorders: prospective evidence from a US national longitudinal study. JAMA Psychiatry. 2016;73(4): 388-95.

102 Patton GC, Coffey C, Carlin JB, Sawyer SM, Lynskey M. Reverse gateways? Frequent cannabis use as a predictor of tobacco initiation and nicotine dependence. Addiction. 2005;100(10):1518-25.

103 Kellow JE, Phillips SF. Altered small bowel motility in irritable bowel syndrome is correlated with symptoms. Gastroenterology. 1987;92(6):1885-93.

104 Aviello G, Romano B, Izzo AA. Cannabinoids and gastrointestinal motility: animal and human studies. Eur Rev Med Pharmacol Sci. 2008;12(Suppl 1):81-93.

105 Hasenoehrl C, Taschler U, Storr M, Schicho $\mathrm{R}$. The gastrointestinal tract-a central organ of cannabinoid signaling in health and disease. Neurogastroenterol Motil. 2016; 28(12):1765-80

106 Izzo AA, Fezza F, Capasso R, Bisogno T, Pinto L, Iuvone T, et al. Cannabinoid CB1-receptor mediated regulation of gastrointestinal motility in mice in a model of intestinal inflammation. Br J Pharmacol. 2001;134(3): 563-70.

107 Izzo AA. Cannabinoids and intestinal motility: welcome to CB2 receptors. Br J Pharmacol. 2004;142(8):1201-2.

108 McCallum RW, Soykan I, Sridhar KR, Ricci DA, Lange RC, Plankey MW. Delta-9-tetrahydrocannabinol delays the gastric emptying of solid food in humans: a double-blind, randomized study. Aliment Pharmacol Ther. 1999;13(1):77-80.

109 Capasso R, Borrelli F, Aviello G, Romano B, Scalisi C, Capasso F, et al. Cannabidiol, extracted from Cannabis sativa, selectively inhibits inflammatory hypermotility in mice. Br J Pharmacol. 2008;154(5):1001-8.

110 Odom-Forren J, Rayens MK, Gokun Y, Jalota L, Radke O, Hooper V, et al. The relationship of pain and nausea in postoperative patients for 1 week after ambulatory surgery. Clin J Pain. 2015;31(10):845-51.

111 Kovacic K, Kapavarapu PK, Sood MR, Li BUK, Nugent M, Simpson P, et al. Nausea exacerbates symptom burden, quality of life, and functioning in adolescents with functional abdominal pain disorders. Neurogastroenterol Motil. 2019;31(7): e13595.

112 Parker LA, Rock EM, Limebeer CL. Regulation of nausea and vomiting by cannabinoids. Br J Pharmacol. 2011;163(7):141122 .

113 Cross-Mellor SK, Ossenkopp KP, Piomelli D, Parker LA. Effects of the faah inhibitor, URB597, and anandamide on lithium-induced taste reactivity responses: a measure of nausea in the rat. Psychopharmacology. 2007;190(2):135-43.
114 McCarthy LE, Borison HL. Antiemetic activity of n-methyllevonantradol and nabilone in cisplatin-treated cats. J Clin Pharmacol. 1981;21(S1):30S-7S.

115 Feigenbaum JJ, Richmond SA, Weissman Y, Mechoulam R. Inhibition of cisplatin-induced emesis in the pigeon by a non-psychotropic synthetic cannabinoid. Eur J Pharmacol. 1989;169(1):159-65.

116 Ferrari F, Ottani A, Giuliani D. Cannabimimetic activity in rats and pigeons of HU 210 , a potent antiemetic drug. Pharmacol Biochem Behav. 1999;62(1):75-80.

117 Simoneau II, Hamza MS, Mata HP, Siegel EM, Vanderah TW, Porreca F, et al. The cannabinoid agonist WIN55,212-2 suppresses opioid-induced emesis in ferrets. Anesthesiology. 2001;94(5):882-7.

118 Van Sickle MD, Oland LD, Ho W, Hillard CJ, Mackie K, Davison JS, et al. Cannabinoids inhibit emesis through cb1 receptors in the brainstem of the ferret. Gastroenterology. 2001;121(4):767-74.

119 Sticht MA, Long JZ, Rock EM, Limebeer CL, Mechoulam R, Cravatt BF, et al. Inhibition of monoacylglycerol lipase attenuates vomiting in suncus murinus and 2-arachidonoyl glycerol attenuates nausea in rats. Br J Pharmacol. 2012;165(8):2425-35.

120 Darmani NA, Johnson JC. Central and peripheral mechanisms contribute to the antiemetic actions of delta-9-tetrahydrocannabinol against 5-hydroxytryptophan-induced emesis. Eur J Pharmacol. 2004;488(1-3): 201-12.

121 Tramer MR, Carroll D, Campbell FA, Reynolds DJM, Moore RA, McQuay HJ. Cannabinoids for control of chemotherapy induced nausea and vomiting: quantitative systematic review. BMJ. 2001;323(7303):1621.

122 Meiri E, Jhangiani H, Vredenburgh JJ, Barbato LM, Carter FJ, Yang HM, et al. Efficacy of dronabinol alone and in combination with ondansetron versus ondansetron alone for delayed chemotherapy-induced nausea and vomiting. Curr Med Res Opin. 2007; 23(3):533-43

123 Duran M, Pérez E, Abanades S, Vidal X, Saura $\mathrm{C}$, Majem $\mathrm{M}$, et al. Preliminary efficacy and safety of an oromucosal standardized cannabis extract in chemotherapy-induced nausea and vomiting. Br J Clin Pharmacol. 2010;70(5):656-63.

124 Kipnes MS, Hollander P, Fujioka K, Gantz I, Seck T, Erondu N, et al. A one-year study to assess the safety and efficacy of the CB1R inverse agonist taranabant in overweight and obese patients with type 2 diabetes. Diabetes Obes Metab. 2010;12(6):517-31. 
125 Pi-Sunyer FX, Aronne LJ, Heshmati HM, Devin J, Rosenstock J; RIO-North America Study Group. Effect of rimonabant, a cannabinoid-1 receptor blocker, on weight and cardiometabolic risk factors in overweight or obese patients: RIO-North America: a randomized controlled trial. JAMA. 2006; 295(7):761-75.

126 Galli JA, Sawaya RA, Friedenberg FK. Cannabinoid hyperemesis syndrome. Curr Drug Abuse Rev. 2011;4(4):241-9.
127 Haney M. Perspectives on cannabis research-barriers and recommendations. JAMA Psychiatry. 2020;77(10):994-5.

128 Hathaway AD. Cannabis users' informal rules for managing stigma and risk. Deviant Behav. 2004;25(6):559-77.

129 Bottorff JL, Bissell LJ, Balneaves LG, Oliffe JL, Capler NR, Buxton J. Perceptions of cannabis as a stigmatized medicine: a qualitative descriptive study. Harm Reduct J. 2013; 10(1):2-10.
130 Crean RD, Crane NA, Mason BJ. An evidence based review of acute and long-term effects of cannabis use on executive cognitive functions. J Addict Med. 2011;5(1):1-8.

131 Volkow ND, Swanson JM, Evins AE, DeLisi LE, Meier MH, Gonzalez R, et al. Effects of cannabis use on human behavior, including cognition, motivation, and psychosis: a review. JAMA Psychiatry. 2016;73(3):292-7. 